\title{
Effect of foliar application of Miyobi on growth and bulb yield of onion
}

\author{
Md. Zahurul Islam ${ }^{1}$, Mhod. Monjurul Alam Mondal' ${ }^{2}$ Md Babul Akter ${ }^{2}$, Mohammad \\ Nurun-Nabi Mazumder ${ }^{3}$, Md. Hasanuzzaman Rani' ${ }^{4}$, M. Obaidul Islam ${ }^{1}$
}

${ }^{1}$ Dept. of Crop Botany, Bangladesh Agricultural University (BAU), Mymensingh-2202, Bangladesh ${ }^{2}$ Crop Physiology Division, ${ }^{3}$ Horticulture Division, ${ }^{4}$ Plant Breeding Division, Bangladesh Institute of Nuclear Agriculture (BINA), BAU Campus, Mymensingh-2202, Bangladesh

$\triangle$ For any information: ask.author@journalbinet.com, Received: 02.03.17, Revised: 12.08.17; Available online: 25 August 2017.

\begin{abstract}
An experiment was conducted at Field Laboratory of the Department of Crop Botany, Bangladesh Agricultural University to investigate the effect of Miyobi (Plant growth regulators, dissolved in water) on morpho-physiological, yield attributes and yield of onion cv. Taherpuri. The experiment comprised of four concentrations of Miyobi viz., 2, 3, 4 and $5 \mathrm{mgL}^{-1}$ and fresh water as control and those were sprayed on onion plant at 40 and 60 days after transplanting. Foliar application of Miyobi increased plant height, leaf number, leaf length, leaf breadth, pseudo-stem diameter, number of roots, root length, absolute growth and yield contributing characters over control. Results revealed that morphological, growth and yield contributing characters and bulb yield increased with increasing concentration of Miyobi up to $4 \mathrm{mgL}^{-1}$ and further increment of hormone concentration had adverse effect on plant growth and development. The highest plant height, leaf number, leaf length and breadth, pseudo-stem diameter, root number, root length, total dry mass production and absolute growth rate was recorded in plants treated with $4 \mathrm{mgL}^{-1}$ Miyobi solution followed by $3 \mathrm{mgL}^{-1}$ with same statistical rank. In control plants where only water was sprayed, the above studied parameters were the lowest. The bulb yield was recorded

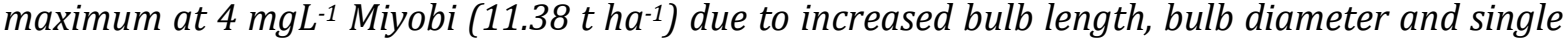

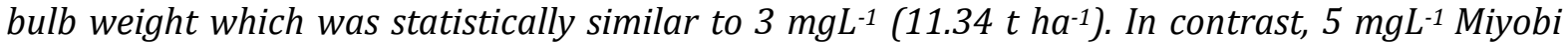
had the adverse effect on yield attributes and yield compared to 3 and $4 \mathrm{mgL}^{-1}$ Miyobi application indicating inhibitory effect of Miyobi at high concentration of $5 \mathrm{mgL}^{-1}$ on onion. Thus Miyobi with 3 or $4 \mathrm{mgL}^{-1}$ may be applied for increased bulb yield of onion.
\end{abstract}

Key Words: Miyobi, Foliar application, Morpho-physiology, Yield and Onion

Cite Article: Islam, M. Z., Mondal, M. M. A., Akter, M. B., Mazumder, M. N., Rani, M. H. and Islam, M. 0. (2017). Effect of foliar application of miyobi on growth and bulb yield of onion. Journal of Bioscience and Agriculture Research,15(01), 1231-1237. Crossref: https://doi.org/10.18801/jbar.150117.151

Article distributed under terms of a Creative Common Attribution 4.0 International License. 


\section{Introduction}

Onion (Allium cepa L.) is the most important of the bulb crops and is one of the important popular spice crops in the world (FAO, 2015). But in Bangladesh, it is extensively used as a spice for cooking purposes. A $100 \mathrm{~g}$ of edible onion bulb contains $1.4 \mathrm{~g}$ protein, $11.2 \mathrm{~g}$ carbohydrate, $12 \mathrm{mg}$ ascorbic acid, $32 \mathrm{mg}$ calcium and 49 calories (MacGillivery, 1981). The onion is relished for its pungency which is due to the presence of a substance allylpropyl disulfide (Rashid, 1983). Recently, research has suggested that onions in the diet play a vital role in preventing heart diseases and other ailments (Agusti, 1990). Onion is known to contain substances having antibiotic properties. Among the spices grown in Bangladesh, onion ranks second in respect of production and area (MOA, 2015). The total area under onion is 52 thousand hectares and its production is about 270 thousand tons (BBS, 2015). But the country requires about 500 thousand metric tons. So, every year Bangladesh has to import large volumes of onion bulbs (about 230 thousand metric tons) at the cost of hard earned foreign exchange (MOA, 2005). With the increase of population, the demand as well as the import of onion is increasing day by day. But due to limitation of land it is not possible to raise the production of the crop horizontally. The expansion of onion cultivation will hamper the cultivation of other crops particularly rice, the staple food grain of Bangladesh. The only way to solve the problem is to increase per hectare yield. Another fact is that the yield of onion has little increased over the last decades. The local cultivars produced poor yield. The average yield per hectare is about 6.82 tons which is much lower than other developed countries where average production is over $17.5 \mathrm{t} \mathrm{ha}^{-1}(\mathrm{FAO}, 2015)$. Onion production is greatly influenced by the use of high yielding varieties, agronomic practices and use of growth regulators. Introduction and cultivation of high yielding varieties of the developed countries are not possible in Bangladesh as they are the crop of temperate regions and are photosensitive in nature requiring long day length for production of bulb (BARI, 1999). To increase the onion production, we need to adapt improve production method and better agronomic practices and use high yielding adapted varieties. Plant growth regulator is another important factor, which can influence the vegetative growth and yield of onion (Maurya and Lal, 1987).

Breeders are successfully developed many crop varieties, which are being used by the farmers. It is postulated that the genetic potentiality of crop varieties touched the higher level to increase their production. There is still chance for improving yield through changes of hormonal treatments. In this connection, use of plant growth regulators (PGRs) might be a useful alternative to increase crop production. Recently, PGRs has been playing important role in agriculture for the betterment of crop growth and yield. Many developed countries like Japan, China, Poland, South Korea etc. have long been using PGRs to increase crop yield. The physiological mechanisms of onion growth are hormonally mediated. PGRs are being used as an aid to enhance crop yield (Nickell, 1982). Additional supply of PGRs control growth and yield in plants. Miyobi, a new plant growth regulator may have many uses to modify the growth, yield and yield attributes of plant. Application of Miyobi enhances growth and yield attributes in mungbean (Rahman, 2006), in sesame (Hossain, 2007) and in Rice (Sarwar et al., 2008). Research works with Miyobi on growth, yield attributes and yield of onion are almost absent. Considering the above facts, the present research work was undertaken to study the effect of Miyobi on growth, morphological features, yield attributes and yield in onion.

\section{Materials and Methods}

The experiment was carried out at the Field Laboratory, Department of Crop Botany, Bangladesh Agricultural University, Mymensingh, during the period from 15 December 2013 to 10 April 2014. The experimental field was medium high land belonging to the Sonatola Soil Series of Grey Floodplain soil under the agro-ecological zone of Old Bahmaputra Flood plain (AEZ-9) (BARC, 2005). The soil was silty loam in texture. Onion variety, Taherpuri was used in the present experiment. The plant growth regulator, Miyobi is marketing by BAL Planning Co. Ltd., Ichinomiyo, Japan. It is a mixture of more than one growth hormones and the composition of the hormone is till unknown. The experiment was laid out in a Randomized Complete Block Design where each treatment replicated thrice. The size of the unit plot was $3.0 \mathrm{~m} \times 2.5 \mathrm{~m}$. Plant to plant and row to row distance were maintained at $15 \mathrm{~cm}$. Urea, triple super phosphate (TSP), muriate of potash (MP) and gypsum were used as source of nitrogen, phosphorus, potassium and sulphur, respectively. Well decomposed cowdung was also applied to the field before final ploughing. Total amount of TSP, MP, gypsum, and 50\% of urea were applied at basal 
doses during final land preparation. The remaining 50\% urea was applied as top dressing at 40 days after transplanting. The doses of fertilizers per hectare were: cowdung $3000 \mathrm{~kg}$, urea $180 \mathrm{~kg}$, TSP 200 $\mathrm{kg}$, MP $170 \mathrm{~kg}$ and gypsum $120 \mathrm{~kg}$ following the fertilizer guide book of BARC (2005). Healthy and uniform sizes about 30 day old seedlings of onion were transplanted. After one week of transplanting, gap filling was done where necessary. Four levels of concentration of Miyobi (dissolved in water) were used in the experiment. The concentrations of Miyobi were 2, 3, 4 and $5 \mathrm{mg} \mathrm{L}^{-1}$ with a control where only water was sprayed. The spray was done to leaves of plants at 40 and 60 days after transplanting (DAT) by a hand sprayer at afternoon. Irrigations were done twice at 30 and 60 DAT. The crop field was weeded twice at 28 and 58 DAT.

To study ontogenetic growth characteristics, a total of four harvests were made and at final harvest, data were collected on some morphological, yield attributes and yield. The first crop sampling was done at 50 days after transplanting (DAT) and continued at an interval of 15 days up to 95 DAT. From each plot, five plants were selected from a side of the plot and uprooted for obtaining data of selected parameters. The plants were separated into leaves, pseudo-stems and roots and the corresponding dry weights were recorded after oven dry at $80 \pm 2{ }^{\circ} \mathrm{C}$ for 72 hours. The growth analysis like absolute growth rate was carried out following the formulae of Hunt (1978). At harvest, 10 plants were randomly selected from each plot for collecting morphological and yield contributing characters. The plots were harvested separately and tagged and brought to the threshing floor. The tops of onion were removed by cutting the leaves $2.5 \mathrm{~cm}$ away from the bulb. The plot yield was converted in tons ha-1. The collected data were analyzed statistically to obtain the level of significance following the analysis of variance (ANOVA) technique and the mean differences were compared by Duncan's Multiple Range Test (DMRT) using the statistical computer package program, MSTAT-C (Russell, 1986).

\section{Results and Discussion}

Foliar application of Miyobi at different concentrations on plant height and leaf production of onion at different growth stages was significant (Figure 01). Results revealed that plant height increased with increased concentration of Miyobi up to $4.0 \mathrm{mgL}^{-1}$. The highest plant height at all growth stages was recorded when Miyobi was applied at the rate of $4.0 \mathrm{mgL}^{-1}$ followed by $3.0 \mathrm{mgL}^{-1}$. The control plant always maintained the shortest plant height at all growth stages. The plant height decreased at 5.0 $\mathrm{mgL}^{-1}$ compared to 3.0 and $4.0 \mathrm{mgL}^{-1}$ might be due toxic effect at this concentration for growth and development of onion. Similar result was also observed in case of leaf production (Figure 02). Leaf number increased with age till 80 DAT followed by a decline due to leaf shading. The concentration of $4.0 \mathrm{mg} \mathrm{L}^{-1}$ produced the highest number of leaves plant ${ }^{-1}$ over its growth period followed by $3 \mathrm{mg} \mathrm{L}^{-1}$ with same statistical rank. In contrast, control plants produced the lowest number of leaves plant ${ }^{-1}$ over its growth period followed by $2.0 \mathrm{mg} \mathrm{L}^{-1}$. The result is supported by the report of Hossain (2007), who reported that application of Miyodo increased plant height and leaf number over control in sesame.
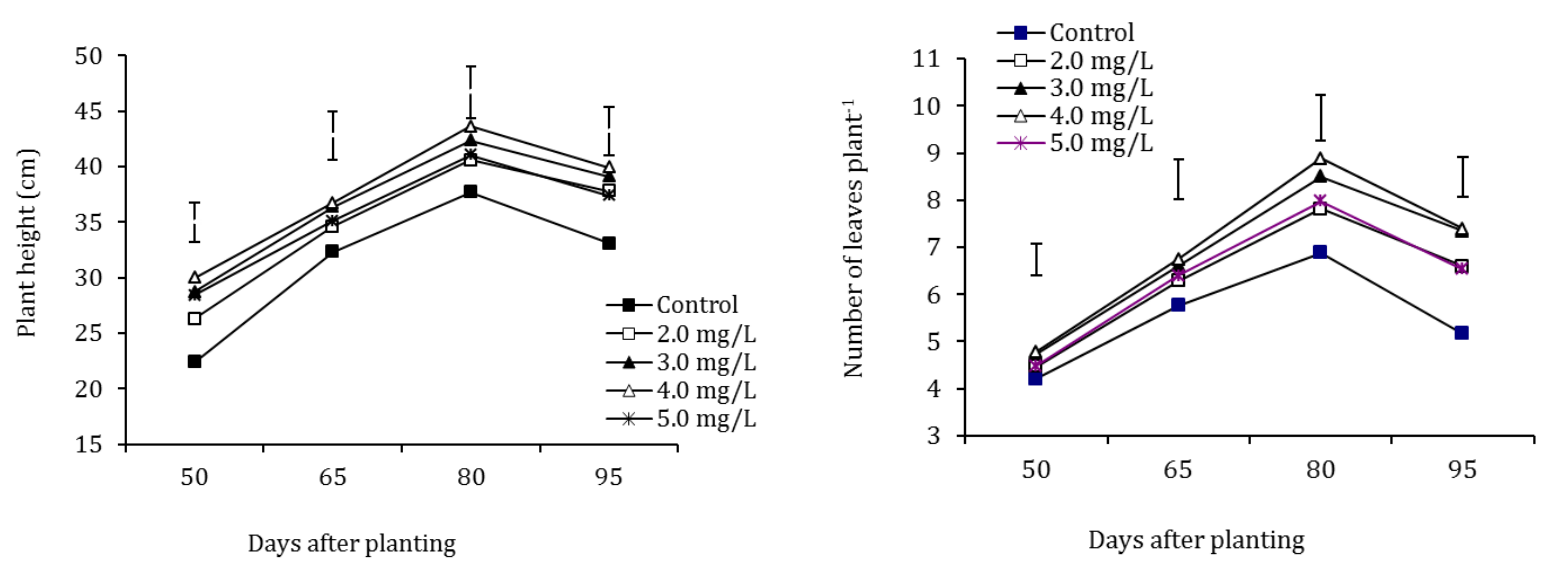

Figure 01. Changes in plant height and leaf number of onion $c v$. Taherpuri at different growth stages due to application of Miyobi. Vertical bars represent LSD ${ }_{(0.05)}$. 
The different concentrations of Miyobi application had significant effect on leaf length and leaf diameter at different growth stages (Table 01). Result showed that leaf length and diameter increased till 80 DAT followed by a decline because of leaf tip die might be due to purple blotch or aging and senescence (Table 01). The higher leaf length and diameter was recorded at 3.0 and $4.0 \mathrm{mgL}^{-1}$ at all growth stages having the highest in $4.0 \mathrm{mg} \mathrm{L}^{-1}$. In control plant where only water was sprayed had the lowest leaf length and diameter all growth stages. The result obtained from the present study is consistent with result of Rahman (2006) in mungbean who stated that the highest leaf length was observed in $4.0 \mathrm{mgL}^{-1}$ of Miyodo. Similar result was also observed in case of pseudo-stem diameter in onion at all growth (Table 02).

Table 01. Different concentrations effect of Miyobi on leaf length and diameter at different growth stages of onion $c v$. Taherpuri

\begin{tabular}{|c|c|c|c|c|c|c|c|c|}
\hline \multirow{2}{*}{$\begin{array}{l}\text { Concentration } \\
\text { of Miyobi }\end{array}$} & \multicolumn{4}{|c|}{ Leaf length $(\mathrm{cm})$} & \multicolumn{4}{|c|}{ Leaf diameter $(\mathrm{cm})$} \\
\hline & 50 DAP & 65 DAP & 80 DAP & 95 DAP & $50 \mathrm{DAP}$ & 65 DAP & 80 DAP & 95 DAP \\
\hline Control & $21.5 \mathrm{~b}$ & $27.0 \mathrm{~b}$ & $30.5 \mathrm{~b}$ & $24.9 \mathrm{c}$ & $0.46 \mathrm{~b}$ & $0.53 \mathrm{~b}$ & $0.67 \mathrm{~b}$ & $0.52 \mathrm{~d}$ \\
\hline $2 \mathrm{mgL}^{-1}$ & $23.1 \mathrm{ab}$ & $29.6 a b$ & $32.2 \mathrm{ab}$ & $28.1 \mathrm{~b}$ & $0.53 \mathrm{a}$ & $0.58 \mathrm{ab}$ & $0.79 \mathrm{a}$ & $0.60 \mathrm{c}$ \\
\hline $3 \mathrm{mgL}^{-1}$ & $25.0 \mathrm{a}$ & $31.6 \mathrm{a}$ & $35.2 \mathrm{a}$ & $31.2 \mathrm{a}$ & $0.54 \mathrm{a}$ & $0.60 \mathrm{a}$ & $0.81 \mathrm{a}$ & $0.68 \mathrm{a}$ \\
\hline $4 \mathrm{mgL}^{-1}$ & $25.5 \mathrm{a}$ & $31.9 \mathrm{a}$ & 36.3 a & $31.4 \mathrm{a}$ & $0.54 \mathrm{a}$ & $0.60 \mathrm{a}$ & $0.83 \mathrm{a}$ & $0.67 a b$ \\
\hline $5 \mathrm{mgL}^{-1}$ & $23.3 \mathrm{ab}$ & $30.2 \mathrm{a}$ & $32.8 \mathrm{ab}$ & $27.9 \mathrm{~b}$ & $0.50 \mathrm{ab}$ & $0.59 \mathrm{ab}$ & $0.78 \mathrm{a}$ & $0.61 b c$ \\
\hline$C V(\%)$ & 5.51 & 6.04 & 6.21 & 6.28 & 5.61 & 4.04 & 3.02 & 5.21 \\
\hline
\end{tabular}

In a column figures having the same letter (s) do not differ significantly at $\mathrm{P} \leq 0.05$.

Table 02. Effect of different concentrations of Miyobi on pseudo-stem diameter at different growth stages of onion $c v$. Taherpuri

\begin{tabular}{l|llll}
\hline \multirow{2}{*}{ Concentration of Miyobi } & \multicolumn{4}{|c}{ Average pseudo-stem diameter (cm) } \\
\cline { 2 - 5 } & $50 \mathrm{DAP}$ & $65 \mathrm{DAP}$ & $80 \mathrm{DAP}$ & $95 \mathrm{DAP}$ \\
\hline Control & $0.59 \mathrm{~b}$ & $0.84 \mathrm{~b}$ & $1.23 \mathrm{c}$ & $1.14 \mathrm{~b}$ \\
$2 \mathrm{mgL}^{-1}$ & $0.61 \mathrm{~b}$ & $0.88 \mathrm{ab}$ & $1.45 \mathrm{~b}$ & $1.27 \mathrm{ab}$ \\
$3 \mathrm{mgL}^{-1}$ & $0.69 \mathrm{a}$ & $0.92 \mathrm{a}$ & $1.55 \mathrm{~b}$ & $1.33 \mathrm{a}$ \\
$4 \mathrm{mgL}^{-1}$ & $0.70 \mathrm{a}$ & $0.93 \mathrm{a}$ & $1.74 \mathrm{a}$ & $1.40 \mathrm{a}$ \\
$5 \mathrm{mgL}^{-1}$ & $0.64 \mathrm{ab}$ & $0.87 \mathrm{ab}$ & $1.50 \mathrm{~b}$ & $1.27 \mathrm{ab}$ \\
\hline$C V(\%)$ & 4.30 & 4.68 & 5.70 & 5.27 \\
\hline
\end{tabular}

Foliar application of Miyobi at different concentrations on root production and root length was significant at all growth stages except 50 DAP for root length (Table 3). Result revealed that root number and root length increased till 80 DAT followed by declined because of some roots died. The highest root number plant ${ }^{-1}$ and root length was recorded in $4.0 \mathrm{mgL}^{-1}$ at all growth stages followed by $3.0 \mathrm{mgL}^{-1}$ with same statistical rank. Control plant had the lowest number of roots plant ${ }^{-1}$ and root length at all growth stages. The result obtained from the present study is consistent with result of Rahman (2006) in soybean who stated that the highest root number was observed in $4.0 \mathrm{mgL}^{-1}$ of Miyodo.

Table 03. Effect of different concentrations of Miyobi on root number and length at different growth stages of onion $c v$. Taherpuri

\begin{tabular}{l|llll|l|l|l|l}
\hline \multirow{2}{*}{$\begin{array}{l}\text { Concentration } \\
\text { of Miyobi }\end{array}$} & \multicolumn{4}{|c|}{ Number of roots plant-1 } & \multicolumn{4}{c}{ Root length (cm) } \\
\cline { 2 - 9 } & $50 \mathrm{DAP}$ & $65 \mathrm{DAP}$ & $80 \mathrm{DAP}$ & $95 \mathrm{DAP}$ & $50 \mathrm{DAP}$ & $65 \mathrm{DAP}$ & $80 \mathrm{DAP}$ & $95 \mathrm{DAP}$ \\
\hline Control & $20.6 \mathrm{~b}$ & $23.4 \mathrm{c}$ & $26.4 \mathrm{~b}$ & $23.6 \mathrm{~b}$ & 3.15 & $4.11 \mathrm{~b}$ & $4.77 \mathrm{~b}$ & $4.44 \mathrm{c}$ \\
$2 \mathrm{mgL}^{-1}$ & $23.6 \mathrm{ab}$ & $26.4 \mathrm{~b}$ & $28.5 \mathrm{ab}$ & $26.3 \mathrm{a}$ & 3.23 & $4.36 \mathrm{ab}$ & $5.13 \mathrm{a}$ & $4.73 \mathrm{ab}$ \\
$3 \mathrm{mgL}^{-1}$ & $24.1 \mathrm{a}$ & $28.1 \mathrm{a}$ & $30.8 \mathrm{a}$ & $26.9 \mathrm{a}$ & 3.29 & $4.50 \mathrm{a}$ & $5.26 \mathrm{a}$ & $4.86 \mathrm{a}$ \\
$4 \mathrm{mgL}^{-1}$ & $24.6 \mathrm{a}$ & $28.8 \mathrm{a}$ & $31.4 \mathrm{a}$ & $27.6 \mathrm{a}$ & 3.38 & $4.60 \mathrm{a}$ & $5.46 \mathrm{a}$ & $4.90 \mathrm{a}$ \\
$5 \mathrm{mgL}^{-1}$ & $23.2 \mathrm{ab}$ & $25.6 \mathrm{~b}$ & $29.0 \mathrm{ab}$ & $24.0 \mathrm{~b}$ & 3.30 & $4.41 \mathrm{a}$ & $5.18 \mathrm{a}$ & $4.60 \mathrm{bc}$ \\
\hline$C V(\%)$ & 8.39 & 3.07 & 6.19 & 4.26 & 4.54 & 4.11 & 4.62 & 2.16 \\
\hline
\end{tabular}

In a column figures having the same letter (s) do not differ significantly at $\mathrm{P} \leq 0.05$. 
The application of different concentrations of Miyobi on onion at all growth stages on total dry matter (TDM) production and absolute growth rate (AGR) was significant (Figure 02). Result revealed that TDM production increased with time up to maturity. The highest TDM production was recorded at 4.0 $\mathrm{mgL}^{-1}$ over growth period $\left(1.99,3.57,5.92\right.$ and 6.65 g plant $^{-1}$ for $50,65,80$ and 95 DAP, respectively) followed by $3.0 \mathrm{mgL}^{-1}\left(1.94,3.43,5.78\right.$ and 6.49 g plant $^{-1}$ for 50, 65, 80 and 95 DAP, respectively) with same statistical rank. In contrast, control plants maintained lower TDM over its growth period (1.34, 2.33, 4.04 and 4.47 g plant $^{-1}$ for $50,65,80$ and 95 DAP, respectively) followed by $5.0 \mathrm{mgL}^{-1}(1.64,2.93$, 4.99 and 5.59 g plant $^{-1}$ for $50,65,80$ and 95 DAP, respectively). Increased TDM at 4.0 and $3.0 \mathrm{mgL}^{-1}$ concentrations was possibly due to increased AGR. The result is supported by the result of Alam (2007) who reported that application of Miyodo (range 1.0-3.0 $\mathrm{mgL}^{-1}$ ) increased TDM over control in lentil with being the highest at $3.0 \mathrm{mgL}^{-1}$ hormone application at 45 DAS. Similar results were also reported by Sarwar et al. (2008) in rice. However, TDM was lower in $5.0 \mathrm{mgL}^{-1}$ compared to lower concentration of Miyobi indicating dose of $5.0 \mathrm{mg} \mathrm{L}^{-1}$ may be toxic for plant growth and development.

The absolute growth rate (AGR) was determined from 50-65 DAT to 80-95 DAT and the results have been presented in Figure 02. The plants of $4.0 \mathrm{mgL}^{-1}$ Miyobi maintained the highest AGR value throughout the growth period (105.9, 156.7 and 49.0 mg plant $^{-1}$ day $^{-1}$ for 50-65, 65-80 and 80-95 DAP, respectively) followed by $3.0 \mathrm{mgL}^{-1}$ Miyobi ( $99.4,156.3$ and $47.5 \mathrm{mg} \mathrm{plant}^{-1}$ day $^{-1}$ for $50-65,65-80$ and 80-95 DAP, respectively). The higher AGR was in 3 and $4 \mathrm{mgL}-1$ than control might be due to increase TDM production. On the other hand, the control plants maintained the lowest AGR over its growth period (66, 110 and 28.6 mg plant $^{-1}$ day $^{-1}$ for 50-65, 65-80 and 80-95 DAP, respectively) for its lower TDM production over time. Further, the maximum AGR was observed at 65-80 DAT in all the treatments. This result is in agreement with the findings of Prasad et al. (1978) who observed the highest AGR value at 65-80 DAS. The declining of AGR after reaching the maximum in all treated plants was the result of abscission of leaves. These results are consistent with the results of Dutta and Mondal (1998).
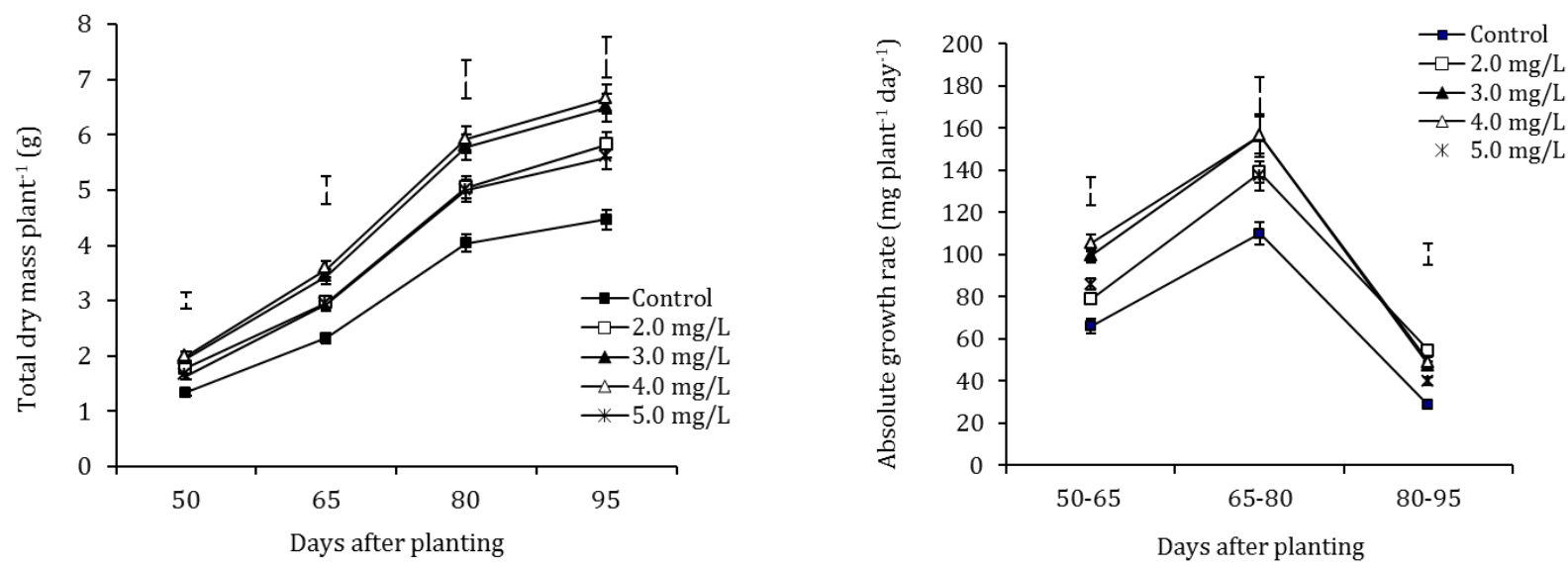

\section{Figure 02. Effect of Miyobi application on absolute growth rate at different growth stages of onion $c v$. Taherpuri. Vertical bars represent LSD $(0.05)$.}

The effect of Miyobi at different concentrations on bulb length and diameter of onion at different growth stages was significant except 50 DAT for bulb length (Figure 03). Results revealed that bulb length and diameter increased with increasing concentration of Miyobi up to $4.0 \mathrm{mg} \mathrm{L}^{-1}$. The highest bulb length and diameter was recorded at $4.0 \mathrm{mgL}^{-1}$ Miyobi application at all growth stages followed by $3.0 \mathrm{mgL}^{-1}$ Miyobi applications. In contrast, control plants always maintained the shorter bulb. The results obtained from the present study were consistent with the result of Deore and Bharud (2001) who stated that bulb diameter increased in $\mathrm{GA}_{3}$ applied plants compared to that in control.

Single bulb weight was significantly influenced by the application of different concentrations of Miyobi (Table 04). Result revealed that single bulb weight increased in Miyobi applied plants than control plants (Table 04). The highest single bulb weight was recorded at $4.0 \mathrm{mgL}^{-1}$ (38.3 g) followed by 3.0 (38.2 g), 5.0 (36.7 g) and $2.0 \mathrm{mgL}^{-1}$ Miyobi application (36.2 g) with same statistical rank. In contrast, control plant produced the smallest bulb size (32.7 g). The single bulb weight was greater in Miyobi applied plant than control due to production of higher bulb diameter. 

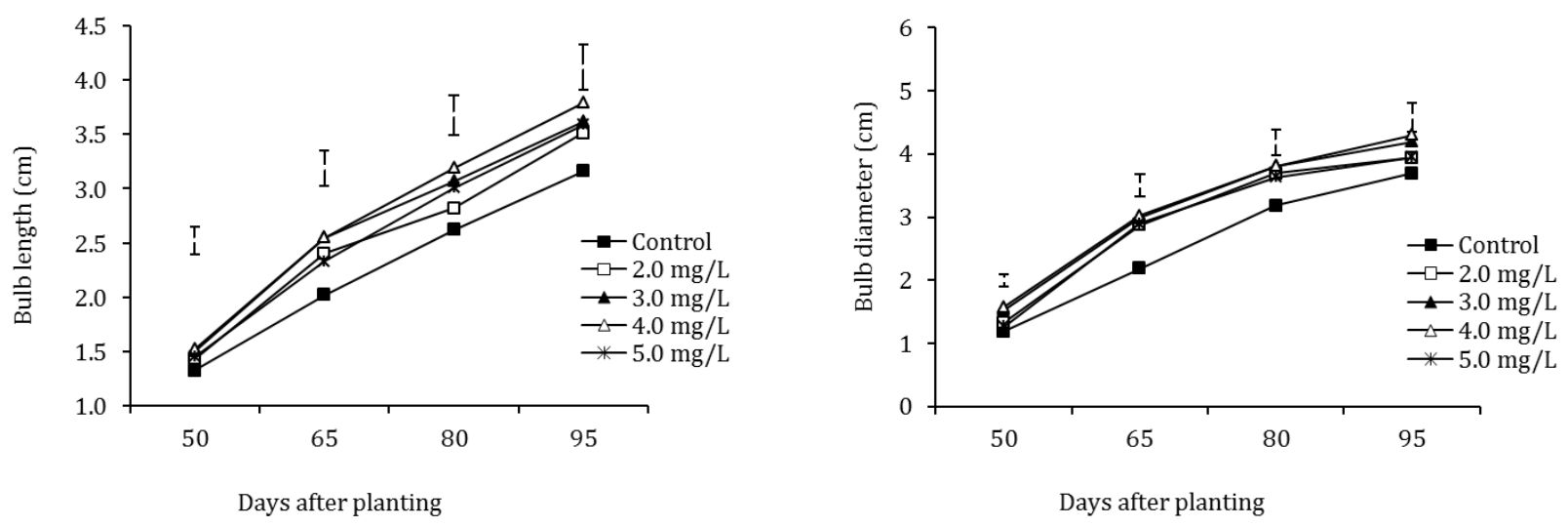

Figure 03. Effect of Miyobi application on bulb development at different plant growth stages of onion $c v$. Taherpuri. Vertical bars represent LSD $(0.05)$.

Bulb yield and yield contributing attributes were significantly influenced by the application of different concentrations of Miyobi except percent dry matter of bulb (Table 04). Result showed that bulb yield increased due to Miyobi application compared to control. The higher seed yield was recorded at $4.0 \mathrm{mg} \mathrm{L}^{-1}\left(11.08 \mathrm{t} \mathrm{ha}^{-1}\right)$ and $3.0 \mathrm{mg} \mathrm{L}^{-1}\left(11.04 \mathrm{t} \mathrm{ha}^{-1}\right)$ with being the highest at $4.0 \mathrm{mg} \mathrm{L}^{-1}$. Bulb yield increased in 3 and $4 \mathrm{mgL}^{-1}$ concentration of Miyobi due to increase in bulb size. In contrast, the lowest bulb yield was recorded in control plant $\left(9.70 \mathrm{t} \mathrm{ha}^{-1}\right)$. Similar results were reported by Rana (2012) in mungbean, by Sarwar et al. (2008) in rice, who observed that seed yield increased due to application of Miyobi.

Table 04. Effect of different concentrations of Miyobi on yield attributes and yield in onion cv. Taherpuri

\begin{tabular}{l|c|c|c|c}
\hline $\begin{array}{l}\text { Concentration of } \\
\text { Miyobi }\end{array}$ & $\begin{array}{c}\text { Single bulb weight } \\
(\mathrm{g})\end{array}$ & $\begin{array}{c}\text { Per cent dry } \\
\text { matter of bulb }\end{array}$ & $\begin{array}{c}\text { Bulb yield } \\
(\mathrm{t} \mathrm{ha}-1)\end{array}$ & $\begin{array}{c}\text { Yield increased over } \\
\text { control (\%) }\end{array}$ \\
\hline Control & $32.7 \mathrm{~b}$ & $7.71 \mathrm{~ns}$ & $9.80 \mathrm{~b}$ & --- \\
$2 \mathrm{mgL}^{-1}$ & $34.2 \mathrm{a}$ & 7.59 & $10.15 \mathrm{ab}$ & $3.57 \mathrm{c}$ \\
$3 \mathrm{mgL}^{-1}$ & $37.2 \mathrm{a}$ & 7.53 & $11.04 \mathrm{a}$ & $12.7 \mathrm{ab}$ \\
$4 \mathrm{mgL}^{-1}$ & $37.3 \mathrm{a}$ & 7.52 & $11.08 \mathrm{a}$ & $13.1 \mathrm{a}$ \\
$5 \mathrm{mgL}^{-1}$ & $35.7 \mathrm{a}$ & 7.75 & $10.91 \mathrm{a}$ & $11.3 \mathrm{~b}$ \\
\hline$C V(\%)$ & 5.17 & 2.66 & 5.33 & 7.20 \\
\hline
\end{tabular}

In a column figures having the same letter (s) do not differ significantly at $\mathrm{P} \leq 0.05$; NS = Not significant.

Considering the yield increment over control, result showed that the yield increment was the highest in $4.0 \mathrm{mgL}^{-1}$ Miyobi applied plant $(13.1 \%)$ followed by $3.0 \mathrm{mgL}^{-1}(12.7 \%)$. The lowest increment was recorded in $2.0 \mathrm{mg} \mathrm{L}^{-1}(3.57 \%)$.

\section{Conclusion}

It may be concluded that foliar application of Miyobi at early growth stage had significant positive influence on plant characters, yield attributes and bulb yield of onion over control; and application of Miyobi @ $4.0 \mathrm{mg} \mathrm{L}^{-1}$ had remarkable superiority for plant growth, yield components and yield over the other doses of Miyobi. Thus we recommended $4.0 \mathrm{mgL}^{-1}$ of miyobi for increased onion bulb yield.

\section{Acknowledgement}

This study was carried out in and supported by the Department of Crop Botany, Bangladesh Agricultural University, Mymensingh-2202, Bangladesh. 


\section{References}

[1]. Agusti, K. T. (1990). Therapeutic and medicinal values of onions and garlic. In: Oniuons and Allied Crops. Vol. III, J. L. Brewster and H. D. Rabinowitch (ed.), CRC press, Boca Raton, Florida, USA. p. 63-70.

[2]. Alam, M. J. (2007). Effect of Miyodo on growth and yield in lentil. M. S Thesis, Dept. Crop Bot., Bangladesh Agric. Univ., Mymensingh.

[3]. BARC (2005). Fertilizer Recommendation Guide. Bangladesh Agricultural Research Council (BARC), Farmgate, Dhaka-1215. p. 34.

[4]. BARI (1999). A study on the adaptability, yield and keeping quality of sixteen exotic cultivars of onion in Bangladesh. Res. Report on Veg. Improvement. Hort Div., Bangladesh Agric. Res. Inst. (BARI), Gazipur 1701. p. 76-77.

[5]. BBS (Bangladesh Bureau of Statistics). (2015). Monthly Statistical Book of Bangladesh. February 2007. Ministry of Planning, Govt. Peoples Rep. Bangladesh. p. 14.

[6]. Deore, B. P. and Bharud, R. W. (2001). Effect of growth substances on the growth and yield of onion cv. N-2-4-1. Maharashtra Journal of Horticulture, 5, 64-67.

[7]. Dutta, R. K. and Mondal, M. M. A. (1998). Evaluation of lentil genotypes in relation to growth characteristics, assimilate distribution and yield potential. LENS Newsl., 25, 51-55.

[8]. FAO (1988). Land resources appraisal of Bangladesh for agricultural development. Report No. 2, UNDP, FAO, Rome, Italy. p. 116.

[9]. FAO. (2015). Production Year Book of 2003. No. 65. Published by FAO, Rome, Italy. p. 54. http://www.fao.org/3/a-i4691e.pdf

[10]. Hossain, M. T. (2007). Effect of Miyodo on growth and yield of sesame. M. S Thesis, Dept. Crop Bot., Bangladesh Agric. Univ., Mymensingh.

[11]. Hunt, R. (1978). Plant growth analysis studies in biology. Edward Arnold Ltd., London. p. 67.

[12]. Islam, M. N. (2006). Effect of GABA on growth, yield attributes and yield in garlic. M. S Thesis, Dept. Crop Bot., Bangladesh Agric. Univ., Mymensingh.

[13]. MacGillivery, J. H. (1981). Vegetable Production. McGraw Hill Book Company Inc. New York. p. 269-273.

[14]. Maurya, C. P. and Lal, H. (1987). Effect of IAA, NAA and GA3 on growth and yield of onion and vegetable chilli. Progressive Horticulture, 19, 203-206.

[15]. MOA (Ministry of Agriculture). (2015). Hand book of Agricultural Statistics, December, 2005. Ministry of Agriculture, Govt. People's Repub. Bangladesh. p. 44.

[16]. Nickell, L. G. (1982). Plant Growth Regulators: Agricultural uses. Springer Verlag, Berlin. p. 122-139. https://doi.org/10.1007/978-3-642-68204-9

[17]. Prasad, V. V. S., Pandey, R. K. \& Saxena, M. C. 1978. Physiological analysis of yield variation in gram genotypes. Indian Journal of Plant Physiology, 21, 228-234.

[18]. Rahman, M. H. (2006). Effect of Miyodo on growth and yield attributes of soybean. M. S Thesis, Dept. Crop Bot., Bangladesh Agric. Univ., Mymensingh.

[19]. Rana, M. I. K., Mondal, M. M. A., Prodhan, A. K. M. A. and Azam, M. G. (2012). Effect of Foliar Application of Miyobi Growth Regulators on Morpho-Physiological Attributes and Yield in Chili. Journal of Environmental Science and Natural Resources, 4 (2), 111-114.

https://doi.org/10.3329/jesnr.v4i2.10158

[20]. Rashid, M. M. (1983). Vegetable Cultivation (in Bengali). Begum Sahela Asad, BARI Residential Area, Gazipur-1701. p. 187-188.

[21]. Russell, D. F. (1986). MSTAT-C Pakage Programme. Crop and Soil Sci. Dept., Michigan Univ., USA.

[22]. Sarwar, A. K. M. G., Sultana, J., Islam, M. O. and Prodhan, A. K. M. A. (2008). Effect of miyodo on growth, yield attributes and yield in t. aman rice cv. br-11. Progressive Agriculture, 19(1), 4549. 